УДК 378.14:37.013.41

DOI 22185186.2019.1.06

Олександр Пономарьов,

Максим Черемський

\title{
ТВОРЧІСТЬ ЯК ВАЖЛИВА УМОВА СТАНОВЛЕННЯ ОСОБИСТОСТІ
}

Сучасний кризовий стан у нашій культурі, науці й економіці великою мірою зумовлений низьким рівнем творчого самовираження особистості. Внаслідок панування авторитарної системи, котра ігнорує особистість із ії неповторним світом думок, почуттів і фантазії, людина все більше скочується до автоматичного конформізму, перетворюючись на бездумний автомат. Дана проблема сягає своїм корінням системи шкільної освіти, котра, на жаль, ще й досі залишається переважно авторитарною. Через те, що навчання носить здебільшого натаскувальний характер, учень позбавляється можливості вільно виявляти власну думку, почуття і фантазію. Тому нині виникає потреба у школі, в якій поважатиметься особистість і створюватимуться відповідні умови для іiі творчого саморозвитку, самовираження та самоствердження.

Творчість відображає духовний світ особистості з іiі мріями, почуттями і прагненнями. Водночас творчість сприяє пізнанню навколишнього світу, активізуючи не лише уяву, але й розумову та емоційновольову сфери особистості. Творчість сприяє появі нових ідей, із яких народжуються твори мистецтва, наукові відкриття і технічні винаходи.

Проблему творчого розвитку особистості вивчали такі відомі вчені та митці, як Ш. Амонашвілі, Л. Виготський, Дж. Гільфорд, І. Зязюн, С. Ільїн, А. Макаренко, А. Маслоу, Дж. Родарі, К. Роджерс, В. Роменець, К. Станіславський, В. Сухомлинський, К. Ушинський, В. Шаталов. Важливу роль творчості в системі професійної підготовки майбутніх фахівців відзначають Г. Васянович, А. Долгарєв, О. Ігнатюк, С. Завєтний, В. Кремень, В. Кудін, В. Лозовой, Н. Ничкало, С. Пазиніч, О. Пономарьов, О. Романовський, С. Сисоєва, О. Сухомлинська та інші вчені. На їхню думку, творчість відкриває в людині невичерпні можливості думки, почуттів і фантазії. Водночас вона сприяє навчально-пізнавальній активності особистості, iї прагненню до знань.

(c) Олександр Пономарьов, Максим Черемський, 2019 
Мета даної статті полягає у визначенні ролі творчості у становленні особистості та пошуку шляхів активізації і розвитку творчого самовираження майбутніх фахівців.

Нині, готуючи фахівців, школа забуває про дуже важливу складову освіти, зокрема про творчий розвиток особистості. Внаслідок переважання репродуктивної, вузькоформатної форми навчання, особистість не має змоги повною мірою виражати власну думку, почуття та фантазію. Дану проблему піднімає відомий американський психолог і педагог Дж. Гільфорд, відзначаючи той факт, що сучасна американська освіта перестала виховувати творчих особистостей. Брак уваги до творчого розвитку особистості робить освіту, за словами вченого, малопродуктивною та неефективною. Тому «головним завданням всебічної освіти, - на думку Гільфорда, - має виступати виховання проникливої, творчо активної особистості» [цит. за 18, с. 317].

Творчість виникає там, де $є$ не лише знання, але творча думка особистості. Внаслідок панування репродуктивної форми навчання, знання, опущені згори, готові істини, узагальнення, умовиводи неначе зв'язують крила мрії, фантазії, творчості дитини, внаслідок чого дитина «з живого, активного, діяльного створіння нерідко перетворюється наче на записувальний пристрій», - зазначав видатний український педагог Василь Олександрович Сухомлинський [15, с. 65].

Саме тому педагог у своїй «Школі радості» приділяв так багато уваги творчому розвитку особистості, наповнюючи знання творчою думкою, почуттям і фантазією. Вивчаючи дитячий світ, В. Сухомлинський дійшов висновку, що дитина дивиться на світ дещо інакше, ніж дорослий. «Дитяче бачення світу - це своєрідна художня творчість», - говорив педагог. Одна дитина бачить в оповитій вечірніми сутінками купі дерев хмарки, які спустилися на відпочинок на землю, інша дитина уявляє в них розлюченого бика, який кинувся рогами на скелю. I це не просто гра дитячої фантазії, але і художній, поетичний елемент мислення. «Кожна дитина не лише сприймає, але й малює, створює, вкладаючи у свій образ власні індивідуальні риси сприйняття, уяви, мислення» [15, с. 43].

На відміну від дорослих, чия уява часто обмежена лише знаннями, отриманими в школі й університеті, діти люблять фантазувати. Справжніх витівників і фантазерів бачив у дітях видатний дитячий письменник і педагог Корній Іванович Чуковський. Так, у своїй відомій книзі «Маленькі діти» митець говорить про те, що кожна дитина, починаючи вже 3 двох років, стає на короткий час геніальним філологом, переробляючи слова, котрі їй не зрозумілі, на свій лад. На думку письменника, 
дорослим слід було б повчитися в дітей словотворенню. Але, на жаль, констатує митець, дитина до п'яти-шестирічного віку втрачає цю здатність, а у десять років від неї не залишається і сліду. «Коли б чуття мови в дитини не притуплювалося з такою швидкістю, вона перевершила б усіх Гоголів та Достоєвських разом узятих» [17, с. 14].

Проте більшість учителів не розуміють дивовижної мови дитячої фантазії, намагаючись підігнати іiі під мову дорослих. Тому В. Сухомлинський радив своїм колегам, щоб вони, навчаючи дітей законам пропорції, перспективи та співвимірності, давали простір і для дитячої фантазії. «Творчість дітей - це глибоко своєрідна сфера їхнього духовного життя, самовираження та самоствердження, де яскраво розкривається індивідуальна самобутність кожної дитини. Цю самобутність неможливо охопити якимись правилами, єдиними й обов'язковими для всіх» [15, с. 51].

Відомий італійський письменник Дж. Родарі вважав, що творчість має бути на першому місці. У своїй книзі «Граматика фантазії» він зауважує, що, якщо ми хочемо навчити дитину думати, ії слід перше навчити придумувати. У навчанні письменник пропонує відштовхуватися від «анімізму» дитини. «Для мене «анімізм» дитини та іiі «артефактизм» $\epsilon$ незмінним джерелом натхнення, і я при цьому зовсім не боюсь викликати та заохочувати дитячі помилки» [12, с. 108].

Визначний учений і педагог, засновник технічної освіти в Україні В. Кирпичов вважав, що фантазію слід плекати вже змалку, як це робили стародавні греки, котрі за допомогою міфів розвивали у своїх учнів уяву і творчу здатність. Тому педагог для розвитку фантазії радив читати дітям казки. «Тепер доволі часто можна зустріти батьків, які повстають проти казок; вони не дають їх своїм дітям, прагнучи виховати тверезих, ділових людей. Я завжди пророкував таким батькам, що їхні діти не стануть ані математиками, ані винахідниками» [6].

Казка є невичерпним джерелом народної мудрості та творчості, черпаючи з якого, дитина пізнає серцем рідний народ, його духовність i культуру. Водночас казка виховує в дитині благородні почуття та прагнення, - зауважував В. Сухомлинський. Слухаючи чи придумуючи казку, дитина переймається долею іiі героїв і разом із ними бореться зі злими силами. Казка відображає духовний світ дитини з їі мріями та сподіваннями. От чому і мова, і мислення дитини краще розвиваються під впливом казки. «Слово казки живе в дитячій свідомості. Серце завмирає у дитини, коли вона слухає чи вимовляє слова, які створюють фантастичну картину. Я не уявляю навчання в школі не лише без слухання, але й без створення казки», - зазначав педагог [15, с. 34]. 
Хтось, можливо, скаже, що казка віддаляє дитину від реальності та об'єктивної дійсності. Проте це не так, адже дитина, слухаючи чи придумуючи казку, відображає в ній світ добра і зла, який ії оточує, та виражає своє ставлення до нього. За допомогою фантазії вона втілює в казкових образах цілком реальних людей, наділяючи їх негативними чи позитивними рисами. Наприклад, в образі Баби Яги дитина може побачити свою вчительку, котра ставить їй двійки, а в Чахлику Невмирущому - злого директора школи. Сама ж дитина асоціює себе або з Іваном Царевичем, або з Василісою Прекрасною, котрі уособлюються в ії свідомості як добрі герої. I де, як не в казці, вона має можливість виявити свої творчі, зокрема винахідницькі, здібності, придумуючи разом зі своїми героями різні хитромудрі плани та пастки проти злих сил.

I все ж скептики скажуть, що сучасні діти не цікавляться казками. Проте чим можна пояснити їхній неймовірний інтерес до книг і фільмів про пригоди хлопчика-чарівника Гаррі Поттера та його друзів. Не менший інтерес викликали фільми про пригоди казкового героя Хоббіта, котрий бореться зі злом і перемагає його. Все частіше кіностудії Голлівуду звертаються до постановок казок Г. Андерсена, братів Грімм, Ш. Перро, Е. Гофмана. Великий інтерес викликають міфи Стародавньої Греції та Риму, скандинавський і німецький епос, арабські казки. Малим дітям дуже подобаються українські та російські народні казки.

На наше глибоке переконання, сьогоденне захоплення дітей комп’ютерами з самого раннього віку значною мірою стало їхньою реакцією на відсутність дива і казки. У комп'ютерних іграх вони й отримують можливість фантазувати і поводитися у світі віртуальної реальності так, як їм хочеться, без зайвої регламентації дії та поведінки, яку нав'язують їм дорослі. Та й самі дорослі часто також звертаються до комп'ютерних ігор, підсвідомо прагнучи надолужити те, чого вони не мали можливості отримати в дитинстві. Розробка ж цих ігор стала не просто однією з успішних бізнес-стратегій і навіть не просто способом самореалізації й самовираження розробників. Вона виступає потужним стимулятором професійного мислення фахівців IT-сфери.

Це тим більше уявляється справедливим через ту особливу роль в активізації творчого самовираження особистості, яку відіграє гра. «Дітей вабить незвичайне - романтика мандрів і пригод, боротьба зі стихійними силами природи» - зазначав В. Сухомлинський [15, с. 180]. Педагог добре розумів вікові особливості розвитку дітей і тому створював усі умови для їхнього гармонійного розвитку, зокрема поєднуючи навчання 3 грою. В. Сухомлинський був прекрасним оповідачем різних казок та іс- 
торій, котрі діти дуже любили слухати й уявляти себе їхніми героями. Якщо педагог розповідав про партизанів, діти грали в партизанів, виховуючи в собі патріотизм і військові навички. Якщо мова йшла про історію Америки, діти уявляли себе на Дикому Заході, втілюючись в індіанців і колоністів. Пригоди Робінзона Крузо надихали дітей оволодівати різними життєво важливими уміннями і навичками, пов'язаними 3 теслярством, землеробством, рибальством тощо.

На відміну від класних чи аудиторних занять, котрі носять здебільшого теоретичний, а то ще й пасивний характер, гра завжди є практичною та креативною. На думку нашого співвітчизника, педагога-реформатора В. Шаталова, характери та здібності дітей в іграх проявляються значно яскравіше, ніж у стандартних умовах уроку. «Не секрет, - зазначає педагог, - що ті, з котрих на уроці і слова не витягнеш, в іграх стають такими активними, якими ми їх у класно-урочних буднях й уявити собі не в змо3i. У грі вони знаходять не лише рівноправність, але й можливість вести за собою інших. Вони можуть повернути хід гри так, що ті, хто вважаються відмінниками, лише руками розведуть...» [8, с. 239].

Без гри немає і не може бути повноцінного розумового розвитку, зазначав В. Сухомлинський. У грі розкривається перед дітьми світ і їхні творчі здібності. Гра в широкому сенсі поняття починається там, де є краса [15, с. 92].

А. Макаренко вважав, що «в дитячому віці гра - це норма, і дитина повинна завжди гратися, навіть коли робить щось серйозне... Треба не тільки дати дитині час погратися, але треба пройняти цією грою все іiі життя. Все життя дитини - це гра. У нас був завод із закордонним устаткуванням. Ми робили фотоапарати «Лійка» 3 точністю до одного мікрона, і все-таки це була гра» [4, с. 469].

Також грою було пройняте життя в славнозвісній колонії імені М. Горького, де вчорашні злочинці почувалися неначе американські колоністи, освоюючи нові землі та борючись за своє існування.

Гра може включати в себе розігрування і розбір казусів зі шкільного чи університетського життя, виробничої практики з подальшим дискусійним аналізом проблемних ситуацій і пошуком раціональних шляхів їх ефективного вирішення. Ігри проводяться також для управлінців.

Ми провели формуючий експеримент з елементами ділової та рольової гри. Зміст гри полягав у пошуку нових стратегій розвитку двох автомобільних гігантів, котрі, внаслідок світової економічної кризи, оголосили про своє банкрутство, а саме американської компанії «GM» та українського заводу «ЗАЗ». Відповідно головними героями 
виступали президент «GM» і генеральний директор «ЗАЗ», котрі мали врятувати свої заводи і відродити їхню минулу славу. Їхніми помічниками були власні творчі можливості, а саме «думка», «фантазія», «почуття» та «воля», ролі яких виконували студенти, виражаючи себе кожен зі своєї позиції.

Група студентів ділилася на дві команди, обираючи підприємство та його керівника. Одночасно розподілялися ролі їх помічників: «думки», «фантазії», «почуття» та «волі». Даний підхід дозволив поєднати в системній цілісності і фахові знання, і психологію, і творчі здібності особистості.

Завдяки своїй нетиповій інтерпретації гра відразу викликала інтерес серед студентів, збудивши в них бажання взяти в ній участь. Тому експеримент проходив легко і невимушено. Студенти весело дискутували, легко перевтілюючись з однієї ролі в іншу. По завершенні керівники мали можливість представити стратегічні плани розвитку своїх підприємств у нових ринкових умовах. Кращий отримував тендер.

Результати формуючого експерименту переконливо засвідчили, що формування і розвиток здатності студентів до творчого самовираження, такої необхідної для їхньої майбутньої успішної професійної діяльності, на 68,0\% залежить від застосування творчих форм і методів навчання. Вплив інших факторів складає лише $32,0 \%$.

Таким чином, аналіз результатів експерименту чітко довів важливість залучення до системи професійної підготовки майбутніх фахівців форм і методів навчання, які пробуджують творчий потенціал особистості, зокрема iї думку, фантазію, почуття та волю.

Ігрову основу мають у собі й такі методи навчання, як лабораторний метод і метод проектів. Лабораторний метод дає змогу почуватися студентові дослідником-експериментатором, який, начебто граючись, отримує можливість відкрити новий закон, розгадати таємницю природи, розкрити властивості того чи іншого предмету та явища. Проектний метод має безпосереднє відношення до творчості, адже студент самостійно ставить перед собою те завдання, яке його найбільше турбує, і вирішує його, вкладаючи в нього свою душу та серце. «Основною умовою успіху тут, - за словами А. Гуманюка, - $\epsilon$ створення атмосфери творчих пошуків, а не копіювання вказівок викладачів. Важливо заохочувати розумне, оригінальне починання учнів, давати простір для їхньої самостійної думки і водночас враховувати реальні можливості кожного учня й умови виконання роботи» [9, с. 121]. 
Як найбільш багатогранну і цікаву царину дитячої та юнацької захопленості світом романтики і фантазії розглядає «технічну творчість» А. Михайлов. «Ніщо інше, - на думку педагога, - не становить такого розмаїття, як діяльність, яка пов'язана з технікою в тих чи інших ії проявах» [7].

На жаль, більшість педагогів віддають перевагу не творчим методам навчання, а авторитарним методам натаскування. Проте педагог, на думку активістів Руху «Cooperazione edukative», «є натхненником, стимулятором творчості, роль якого не зводиться до передачі знань у «розфасованому» вигляді, по стільки-то на день; учитель - не приборкувач необ’їжджених коней і не дресирувальник тюленів. Це доросла людина, яка знаходиться 3 дітьми для того, щоб передати їм найкраще, що в неї $\epsilon$, щоб розвивати в собі самому навички творчості й уяви, конструктивно брати участь у різних видах діяльності» [цит. за 12, с. 181].

Розуміючи дану проблему, відомий український педагог Іван Андрійович Зязюн розробив курс з основ педагогічної майстерності та творчості, що якраз мав на меті виховання у педагога творчих умінь і навичок [10]. В основу курсу була покладена «система підготовки актора» видатного режисера, актора та педагога К. Станіславського. Дана «система» дає змогу педагогові поглянути на педагогіку не лише як на науку, але й як на мистецтво. Сутність «системи Станіславського» полягає у «природному збудженні творчості органічної природи з ії підсвідомістю» [13, с. 4].

Завдяки таким творчим прийомам режисера, як магічне «коли б» та «пропоновані обставини», педагог, як і актор, має можливість перевтілюватися і подорожувати в часі. К. Станіславський вважав, що творчість починається з того моменту, коли в душі та в уяві артиста виникає магічне творче «коли б». «Поки існує реальна дійсність, реальна правда, якій, природно, не може не вірити людина, творчість ще не починалася. Але от виникло творче «коли б», тобто вигадана, уявлювана правда, якій артист уміє вірити так само щиро, але з іще більшим захопленням, ніж істинній правді. Зовсім так само, як вірить дитина в існування своєї ляльки і всього життя в ній і навколо неї. 3 моменту виникнення «коли б» артист переноситься $з$ площини дійсного, реального життя у площину іншого, утворюваного, уявлюваного ним життя. Повіривши йому, артист може починати творити» [14, с. 325].

Саме такого підходу бракує нашій академічній школі, переобтяженій класичними знаннями, які часто просто не сприймаються студентом через те, що бракує чогось, що могло б оживити ці знання, наповнити їх живим трепетом думки, почуття і фантазії. Відомий російський педагог Є. Ільїн вважає, що сучасній школі бракує художників, здатних оживи- 
ти урок, вдихнути в нього життя. Самі учні у своїх творах дають підказку вчителям, якими вони хотіли б їх бачити - «розумними - так; ерудованими - звичайно; вміючими - безумовно. Але у всіх на першому плані стояло: цікавими, оригінальними, вигадливими» [3, с. 27].

Тому педагог має бути не просто вчителем чи викладачем, a, перш за все, творчою особистістю i справжнім артистом. Як зауважує М. Поташник, - «мова йде не лише про зовнішні чинники (інтонація, міміка, жест, поза), хоч і вони мають неабияке значення для створення творчої атмосфери на уроці. Артистизм - це здатність до перевтілення, блискавичної перебудови у нові образи, переключення у нові ситуації i, найголовніше, - вміння жити тими ідеями, які вчитель передає учням на уроці, жити щиро і стільки разів, скільки знадобиться» [11, с. 69].

Артистизм, на думку С. Ільїна, не примха і не своєрідність чиєїсь манери, а «найважливіший (сучасний!) навчальний засіб, без котрого сьогодні не працює ані урок, ані книга» [3, с. 27].

Саме тому так важливо педагогу вивчати художні твори, відкриваючи для себе світ справжніх почуттів і вчинків. Мистецтво, маючи, за словами Л. Виготського, перетворювальну природу, привносить у наше життя те, чого ще немає, спонукаючи нас до дій і змін [2].

Прекрасною можливістю познайомитися з мистецтвом і взяти безпосередню участь у його творенні виступає художня самодіяльність, яка вирізняється своєю відкритістю та демократичністю. В Палаці студентів Національного технічного університету «Харківський політехнічний інститут» (НТІ «ХПІ») існує велика кількість гуртків і студій художньої самодіяльності на будь-який смак. Тут відбуваються різні фестивалі, конкурси, творчі вечори, Дні факультетів тощо. Серед викладачів НТУ «ХПІ» $є$ педагоги, котрі поєднують науку і мистецтво. Недарма при заснуванні університет називався Харківським технологічним інститутом, охоплюючи тим самим і мистецтво, і науку. Його випускниками свого часу були такі визначні особистості української культури, науки і техніки, як Гнат Хоткевич, Левко Мацієвич, Олександр Коваленко, Юрій Коллард, Марко Рейзен, Володимир Фокін, Аркадій Інін та багато інших визначних митців і вчених. Нині в НТУ «ХПІ» працюють такі викладачі, як О. Горілий, О. Романовський, С. Шелковий, М. Шепілов та інші, котрі гармонійно поєднують у собі інженерні здібності з мистецькими. Прикладом творчого синтезу поезії та знань $є$ навчальний посібник із термодинаміки Е. Братути.

Тому надзвичайно важливою умовою забезпечення творчого розвитку молоді виступає високий потенціал креативності кращих педагогів, 
яких відомий український педагог і поет Г. Васянович справедливо вважає педагогічною елітою. На його переконання, «сучасна педагогічна еліта має піднятися на значно вищий щабель не лише інтелектуального, а й загальнокультурного, духовно-морального розвитку. Сучасна педагогічна еліта має бути вкоріненою в українську культуру, в іiі традиції, вона має стати консолідуючим ядром нації» [1, с. 104].

Самодіяльність означає самоактуалізацію особистості, іiі здатність виражати власну думку, почуття і фантазію та втілювати їх у життя. На думку американського психолога та педагога А. Маслоу, «важливою характеристикою самоактуалізуючих людей виступає їхня здатність до творчості, яку кожен із них виражає по-своєму. Творчості самоактуалізуючої особистості притаманна наївність і універсальна креативність незіпсутих дітей» [19].

Тож кожен педагог має володіти високим рівнем самоактуалізації, виявляючи в собі те найкраще, що робить його по-справжньому оригінальним і цікавим для себе та інших.

Отже, як зауважує В. Караковський, здатність до творчості виступає найважливішою якістю сучасної людини, нагальною соціальною потребою в цілому. Тому вчити творчості слід уже зі шкільної лави. «За дітьми справа не стане. Творчість - норма дитячого розвитку. Значно складніше 3 дорослими. Адже творчість часто пов'язана $з$ ризиком, а за останні роки охочих ризикувати в школі майже не залишилось. Як тут не згадати А. С. Макаренка: відмовитися від ризику означає відмовитися від творчості» [5, с. 79].

Тому навчання має бути тісно пов'язане з творчістю. Адже педагогіка, за визначенням К. Ушинського, є «мистецтвом - найбільшим, складним, найвищим і найнеобхіднішим зі всіх мистецтв» [16, с. 179].

Таким чином, становлення особистості неможливе без самовиявлення та розвитку їі творчого потенціалу. Саме через творчість людина виражає власну думку, почуття, фантазію та волю. У творчості проявляється іiі ставлення до себе та до навколишнього світу. Творчість розкріпачує думку людини, відкриваючи їй шлях до нових звершень і досягнень. Тому професійна підготовка майбутніх фахівців має передбачати не лише оволодіння професійними знаннями, уміннями і навичками, але й творче становлення особистості. Як зауважує Дж. Гільфорд, «творчість $є$ ключем до освіти в ії найповнішому сенсі та до вирішення найбільших проблем людства» [18, с. 326].

В умовах ринку та відповідного загострення конкуренції успішність професійної діяльності фахівця істотною мірою залежатиме не тільки від 64 
його компетентності, але й від інноваційної спрямованості його мислення і розвитку креативних здібностей. Ці якості в їх системній цілісності утворюють особистісний потенціал фахівця, реалізація якого стає результатом його становлення як професіонала й особистості.

\section{Jimepamypa:}

1. Васянович Г., Будник О. Педагогічна еліта як феномен сучасності: духовноморальний контекст. Лідер. Еліта. Суспільство. 2017. № 1. С. 6-108.

2. Выготский Л. С. Психология искусства. М. : Искусство, 1986. 573 с.

3. Ильин Е. Н. Шаги навстречу: Из опыта работы учителя. М. : Просвещение, 1986.32 с.

4. Історія української школи і педагогіки : Хрестоматія / Упоряд. О. О. Любар; За ред. В. Г. Кременя. К. : Т-во «Знання», КОО, 2003. 766 с.

5. Караковский В. А. Любимые мои ученики. М. : Знание, 1987.80 с.

6. Кирпичев В. Л. Значение фантазии для инженеров. Известия Киевского политехнического института. К. : Тип. С. В. Кульженко, 1903. С. 7-25.

7. Михайлов А. А. Техническое творчество школьников. М. : Просвещение, 1969.268 с.

8. Мудрость воспитания : книга для родителей / Сост. Б. М. Бим-Бад, Э. Д. Днепров, Г. Б. Корнетов. М. : Педагогика, 1987. 288 с.

9. Педагогика / под ред. А. П. Кондратюка. К. : Вища школа, 1976. 376 с.

10.Педагогічна майстерність / за ред. І. А. Зязюна. К. : Вища школа, 1997. 349 с.

11. Поташник М. М. Как развивать педагогическое творчество. М. : Знание, 1987. 80 с.

12.Родари Дж. Грамматика фантазии. Введение в искусство придумывания историй. М. : Прогресс, 1978. 212 с.

13.Станиславский К. С. Работа актёра над собой. Ч. 1 : Работа над собой в творческом процессе переживания. Дневник ученика. М. : Искусство, 1985. 479 с.

14.Станіславський К. Моє життя в мистецтві. К. : Мистецтво, 1955. 480 с.

15.Сухомлинский В. А. Сердце отдаю детям. К. : Радянська школа, 1988. 272 с.

16.Ушинский К. Д. Избранные педагогические сочинения. Т. 1. М. : ГУПИ МП РСФСР, 1953. $640 \mathrm{c.}$

17.Чуковский К. Маленькие дети. Л. : Красная газета, 1928. 96 с.

18.Fasko D. Education and Creativity. Creativity Research Journal. 2000-2001. Vol. 13. No. 3\&4. P. 317-327.

19. Maslow A. Self-actualizing people: a study of psychological health. Motivation and Personality. USA : Abraham H. Maslow, 1970. P. 149-180.

\section{References (transliterated and translated):}

1. Vasianovych H. P., Budnyk O. B Pedahohichna elita yak fenomen suchasnosti: dukhovnomoralnyi kontekst (Pedagogical elite as phenomenon of the present: spiritual and moral context). Lider. Elita. Suspilstvo (Leader. Elite. Society). 2017. No 1. P. 6-108 (in Ukrainian).

2. Vygotskiy L. S. Psihologiya iskusstva (Psychology of art). Moscow, 1986. 573 p. (in Russian).

3. Il'in, E. N. Shagi navstrechu: Iz opyta raboty uchitelia (Steps to meet: From experience of working as a teacher). Moscow, 1986. 32 p. (in Russian).

4. Istoriya ukrainskoi shkoly i pedahohiky : Khrestomatiya (The history of Ukrainian school and pedagogics : Reader) / Compiler O. O. Lubar; ed. by V. H. Kremen. Kyiv, 2003. 766 p. (in Ukrainian). 
5. Karakovskiy V. A. Liubimye moi ucheniki (Beloved my pupils). Moscow, 1987. 80 p. (in Russian).

6. Kirpichev V. L. Znachenie fantazii dlia inzhenerov (Meaning of fantasy for engineers). Izvestiya Kievskogo politehnicheskogo instituta (News of Kyiv polytechnic institute). Kyiv, 1903. P. 7-25. (in Russian).

7. Mihailov A. A. Tehnicheskoe tvorchestvo shkol'nikov (Technical creativity of pupils). Moscow, 1969. 268 p. (in Russian).

8. Mudrost' vospitaniya : Kniga dlia roditelei (Wisdom of education : The book for parents). / Comp. B. M. Bim-Bad, E. D. Dneprov, G. B. Kornetov. Moscow, 1987. 288 p. (in Russian).

9. Pedagogika (Pedagogics) / Ed. A. P. Kondratiuk. Kyiv, 1976. 376 p. (in Russian).

10.Pedahohichna maisternist (Pedagogical skills) Ed. I. A. Ziaziun. Kyiv, 1997. 349 p. (in Ukrainian).

11.Potashnik M. M. Kak razvivat' pedagogicheskoe tvorchestvo (How to develop pedagogical creativity). Moscow, 1987. 80 p. (in Russian).

12.Rodari J. Grammatika fantazii. Vvedenie v iskusstvo pridumyvania istoriy (The grammar of fantasy. Introduction in the art of inventing stories). Moscow, 1978. 212 p. (in Russian).

13.Stanislavskiy K. S. Rabota aktiora nad soboi. - Ch. 1: Rabota nad soboy v tvorcheskom protsesse perezhivaniya. Dnevnik uchenika (The work of actor at himself/herself. - Part 1: The work at oneself in creative process of experience. Leane'sr diary). Moscow, 1985. 479 p. (in Russian).

14.Stanislavskyi K. Moe zhyttia v mystetstvi (My life in art). Kyiv, 1955. 480 p. (in Ukrainian).

15. Suhomlinskiy V. A. Serdtse otdaiu detiam (I give my heart to children). Kyiv, 1988. 272 p. (in Russian).

16.Ushinskiy K. D. Izbrannye pedagogicheskie sochineniya (Selected pedagogical works). Vol. 1. Moscow, 1953. 640 p. (in Russian).

17. Chukovskiy K. Malenkie deti (The little children). Leningrad, 1928. 96 p. (in Russian).

18.Fasko D. Education and Creativity. Creativity Research Journal. 2000-2001. Vol. 13, Nos. 3\&4. P. 317-327. (in English).

19. Maslow A. Self-actualizing people: a study of psychological health. Motivation and Personality. USA : Abraham H. Maslow, 1970. P. 149-180 (in English).

Стаття надійшла до редакції 18.10.2018

\section{О. Пономарьов, М. Черемський}

Творчість як важлива умова становлення особистості

У статті піднято проблему творчого розвитку особистості, іiі самовираження та самоствердження. Внаслідок панування авторитарної форми навчання і виховання учень і студент не мають можливості повною мірою виявляти власну думку, почуття та фантазію. Це призводить до зниження рівня успішності й інтересу до навчання та фахової підготовки. Водночас становлення особистості значно уповільнюється. Сьогодні, в часи ринкової економіки, даний підхід до навчання не є ефективним, 
адже в сучасному світі понад усе цінується здатність людини виражати власну думку, висувати нові ідеї та втілювати їх у життя. Тому освіта має не придушувати, а плекати творчий потенціал особистості, яким володіє кожна, без винятку, людина. Слід лише знайти відповідний підхід до неї. Автори пропонують будувати навчання на повазі до особистості, iii можливостей і здібностей. Водночас педагог має володіти належним рівнем педагогічної культури, майстерності та творчості.

Ключові слова: творчість, духовний світ особистості, самовираження, самоствердження, творчі методи навчання, артистизм.

\section{O. Ponomariov, M. Cheremskyi}

\section{Creativity as a Very Important Condition of Personality's Formation}

The article raised the problem of a personality's creative development, his/her self-expression and self-affirmation. Due to the domination of authoritarian education, the students have no possibility to express own thoughts, emotions and fantasy in full. This leads to a decrease in the level of success and interest in education. At the same time the formation of a personality is considerably slowing down. Today in market economics times authoritarian education is not effective, indeed, in today's world, the ability of a person to express his or her own opinion, to put forward new ideas and to implement them is most valued. Therefore, education should not suppress, but cherish a personality's creative potential. Every person, without exception, possesses such a potential - you just have to find a suitable approach to him/her. The authors propose to build a learning process basing on the respect for a personality, his/her capabilities and abilities. The teacher must have high level of creativity and pedagogical culture and skills.

Key words: creativity, inner life of personality, self-actualization, creative methods of education, artistic skills.

Рецензент - доктор педагогічних наук, професор Г. П. Васянович 